\title{
ANALYSIS INDICATOR OF FACTORS AFFECTING HUMAN DEVELOPMENT INDEX (IPM)
}

\author{
Windya Wahyu Lestari ${ }^{1}$, Victoria Efrida Sanar $^{2}$ \\ ${ }^{1,2}$ Departement of Geography Education \\ Postgraduate State University of Malang, Indonesia \\ E-mail: wahyuiin1993@gmail.com
}

DOI: $10.19184 /$ geosi.v2i1.7333

\begin{abstract}
Article History: Received Date $1^{\text {st }}$ April 2018, Received Revised $21^{\text {th }}$ April 2018, Accepted Date $27^{\text {th }}$ April 2018, Published Date $30^{\text {th }}$ April 2018
\end{abstract}

\begin{abstract}
The purpose of this study is to determine how big the influence of the indicators of factors that affect the Human Development Index. In addition, to determine the relationship of indicators of factors that affect the Human Development Index, to determine the development of human development of variables. That way can provide a standard against a State in improving the quality of human resources.Using the SPSS application method, this paper found that the variables that significantly influence the indicators of factors affecting the Human Development Index are life expectancy index, education index and income index. The estimation result using Correlasion Pearsonshows that $14.788 \%$ is the variation of each observation is the same.

Keywords : : Human Development Index, Life Expectancy Index, Education Index, Revenue Index.
\end{abstract}

\section{INTRODUCTION}

Human Development Index is one of the standard for a State in viewing the quality of human resources. The Human Development Index (HDI) has several measures of status or classification.Given these measures raises indicators in the factors affecting the Human Development Index.These indicators will determine how the quality of a country's human resources.

The Human Development Index itself was first published by UNDP through the 1996 Human Development Report, which then continues each year.In this publication human development is defined as "a process ofenlarging people's choices" or a process 
that improves society's aspects of life.This most important aspect of life is seen from a healthy age and healthy life, adequate educational level , and decent standard of living. ( Mohammad Bhakti Setiawan \& Abdul Hakim, page 19).

Regarding UNDP says about the most important aspect of life, that aspect must be considered for a State.This is because if one of the most important aspects of life is not balanced with other aspects, the country automatically is still lacking in the quality of its natural resources.So is the Human Development Index does not stand alone in determining the quality of a country's resources.Necessary indicators to facilitate a State in analyzing the development of human development.

Explanation of indicators of factors affecting the Human Development Index as follows:

1. Life expectancy index

Life expectancy index shows the number of years of life that is expected to be enjoyed by residents of a region. Incorporating information on the number of births and deaths per year of variable 0 is expected to reflect the average length of life as well as community duplexes. Due to the difficulty of getting information from people who have died over a certain period of time, the use of indirect methods (Brass method, varianTrussel) is used to reduce life expectancy.

The basic data required in this method is the average of live birth children and the average child is still alive from the ever married woman. The process of calculating life expectancy is provided by the Mortpak program. One way is to standardize life expectancy against its maximum and minimum values.

2. Education Index

Calculation of Education Index (IP) includes two indicators namely literacy rate (Lit) and average school (MYS).Population in use ispopulation aged 15 years and over because in reality the population agedthere are already those who quit school.These limits are necessary to reflect the actual conditions in view of the fact that the population less than 15 years old is still in the process of being school or going to school so it is not appropriate for the average length of school. 
These two indicators of education are raised in the hope of reflecting the level of knowledge (a reflection of Lit numbers), where Lit is the proportion of the literate population in a whole population population. While the reflection of the number MYS.

\section{Purchasing Power Parity / PPP}

To measure the dimensions of decent living standards (purchasing power), UNDP uses an indicator known as real per capita GDP adjusted. For subnational (provincial or district / city) HDI calculations do not use per capita GDP, because per capita GDP only measures the production of a region and does not reflect the real purchasing power of the community which is the concern of IPM. To measure the purchasing power of the population among provinces in Indonesia, BPS uses the average data on consumption of 27 selected commodities from the National SocioEconomic Survey (SUSENAS) which is considered the most dominant in consumption by Indonesians and has been standardized to be comparable between regions and between time-adjusted with a PPP index.

One of the researchers who examined the Indicators of factors affecting HDI is Gustav Ranis \& Frances Stewart (2005). In a follow-up study, Ranis and Stewart expanded the scope of the study to cover almost all countries in the world where UNDP has been recorded in terms of its human development index (IPM). Factors affecting the human development index (HDI), they use explanatory variables of GDP per capita growth rate (GDP), literacy shortfall reduction (LIT), percentage of gross domestic investment (GDP) per GDP (gross domestic investment as percentage of GDP = GDI), percent of exports to GDP (exports as percentage of GDP = EXP), poverty headcount (POV) and dummy for the Middle East region (dME), Asia and Latin America (dAL). Research conducted on 85 countries in the world. The results of their researchestimate as shown in Table 1. 
Table 1. Results of Research Estimation Gustav Ranis \& Frances Stewart (2005)

\begin{tabular}{ccc}
\hline $\begin{array}{c}\text { Variabel } \\
\text { Independen }\end{array}$ & $\begin{array}{c}\text { Variabel Dependen: IPM } \\
\text { Koefisien }\end{array}$ & $\mathrm{t}$-rasio \\
\hline GDP & 2,96 & $3,81^{* *}$ \\
LIT & 1,94 & 1,53 \\
GDI & 2,80 & $2,39^{*}$ \\
EXP & 1,80 & 0,42 \\
POV & 16,4 & $4,94^{* *}$ \\
$d \mathrm{ME}$ & 0,21 & 1,00 \\
$d \mathrm{AS}$ & 0,42 & $3,14^{* *}$ \\
$d \mathrm{AL}$ & 0,36 & $2,40^{*}$ \\
Konstanta & 1,89 & $3,77^{* *}$ \\
Adj $R^{2}$ & 0,79 & \\
$N$ & 85 & \\
\hline
\end{tabular}

*Coefficientsignificant at a rate of $5 \%$

$* *$ Coefficientsignificant at the rate of $1 \%$

The estimation results show that not all independent variables are significant to human development index (HDI). Only the variable of economic growth (GDP), gross domestic investment (GDI) and the number of poor (POV) are significant, excluding dummy variables. This model has the disadvantage of including an explanatory variable of the literacy rate, where that variable is a component of the HDI composite. In addition, GDP and GDI variables may not be included together because GDI is part of GDP (estimation error due to multicolinearity).

\section{METHODS}

This data source uses the original secondary data ie data sources released by BPS, BAPPEDA, UNDP and related recordswith research from the Central Bureau of Statistics in several publications.Serial data used in this study was limited to taking the components of the Human Development Index in Indonesia in 2010 using the Pearson Correlation Model SPP application, it can show the analysis of indicators of factors that affect the Human Development Index.

\section{RESULTS AND DISCUSSION}

1. Results

The results of data analysis on the factors that influence the Human

Development Index in the form of tables as follows. 


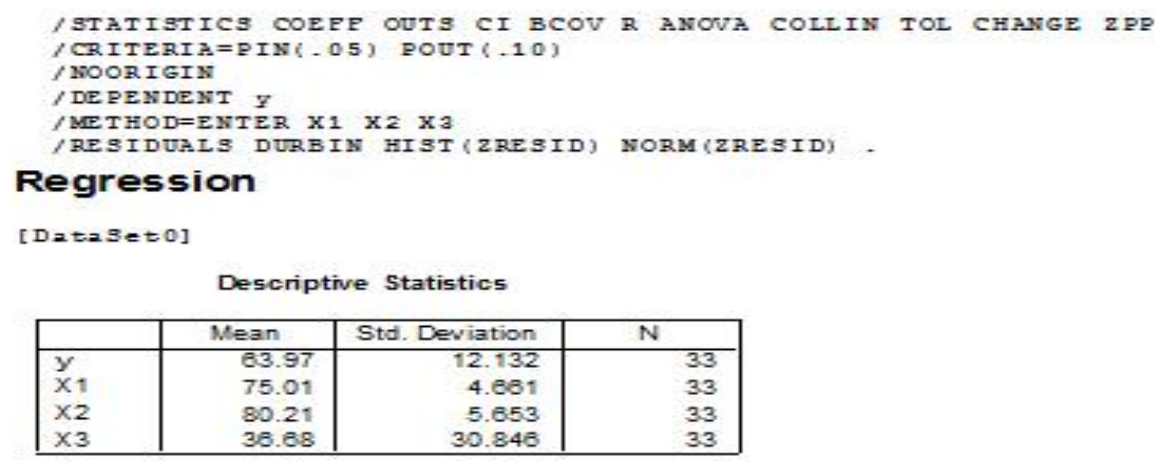

\begin{tabular}{|c|c|c|c|c|c|}
\hline \multicolumn{6}{|c|}{ Correlations } \\
\hline & & $y$ & X1 & $\times 2$ & $\times 3$ \\
\hline \multirow[t]{4}{*}{ Pearson Correlation } & $y$ & 1.000 & .823 & .545 & 988 \\
\hline & $\times 1$ & .823 & 1.000 & .163 & .554 \\
\hline & $\times 2$ & .545 & .163 & 1.000 & .435 \\
\hline & $\times 3$ & .986 & .554 & .435 & 1.000 \\
\hline \multirow[t]{4}{*}{ Sig. (1-tailed) } & $y$ & &.$\infty 00$ & .001 & .000 \\
\hline & $x_{1}$ & .000 & & .183 & .000 \\
\hline & $\times 2$ &.$\infty 0_{1}$ & .183 & & .006 \\
\hline & $\times 3$ &.$\infty 00$ &.$\infty 00$ & .006 & \\
\hline \multirow[t]{4}{*}{$N$} & $y$ & 33 & 33 & 33 & 33 \\
\hline & $x_{1}$ & 33 & 33 & 33 & 33 \\
\hline & $\times 2$ & 33 & 33 & 33 & 33 \\
\hline & $\times 3$ & 33 & 33 & 33 & 33 \\
\hline
\end{tabular}

1) $\underline{H}_{\mathrm{O}} \underline{\&} \underline{\mathrm{H}}_{i} \underline{\text { hypothesis formulation: }}$

1. $\mathrm{H}_{\mathrm{O}}$ : There is no relationship between Life expectancy Index against Human development Index.

$\mathrm{H}_{\mathrm{i}}$ : There is a significant relationship between life expectancy index on human development index.

Hypothesis testing :

If the probability value (p) $<0.005$ means that Ho is rejected, Hi is accepted If the probability value (p) $\geq 0.005$ means Ho accepted, Hi is rejected.

From the correlation table in the attachment 3.1 can be tested the hypothesis is obtained significant value of life expectancy index (probability value) $=0.001$, then the hypothesis test is $0.001<0.005$ then Ho rejected, Hi accepted which means that there is influence of income index on human development index.

2. $\mathrm{H}_{\mathrm{O}}$ : There is no correlation between education indices to human development index. 
$\mathrm{H}_{\mathrm{i}}$ : There is a significant correlation between education index to human development index

Hypothesis testing :

If the probability value (p) $<0.005$ means that Ho is rejected, Hi is accepted If the probability value (p) $\geq 0.005$ means Ho accepted, Hi is rejected

Analysis of data on the calculation of HDI SPSS program obtained that the correlation table shows the significant value of education index is 0.000.Then the hypothesis test is $0.000<0.005$ then Ho is rejected, Hi accepted.This means there is an influence of educational index on human development index.

3. $\mathrm{H}_{\mathrm{O}}$ : There is no relationship between income index against Human development index.

$\mathrm{H}_{\mathrm{i}}$ : There is a significant relationship between income Index on Human development Index .

Hypothesis testing:

If the probability value $(\mathrm{p})<0.005$, meaning Ho is rejected, Hi accepted

If the probability value $(\mathrm{p}) \geq 0.005$, meaning Ho accepted, Hi rejected

Analysis of data of IPM calculation on SPSS program obtained that from correlation table significant value of income index is 0,003 , then probability value (p) $<0,005=0,003<0,005$ Ho rejected, Hi accepted. Thus it can be hypothesized that there is influence of income index on human development index.

Formulation of the R-Squer Change Model hypothesis

4. $\mathrm{H}_{\mathrm{O}}$ : There is no relationship between Life expectancy Index against Human development Index.

$\mathrm{H}_{\mathrm{i}}$ : There is a significant relationship between life expectancy index on human development index

Hypothesis testing:

If significant value $\mathrm{F}$ arithmetic $<0.005$ (F table), it means Ho rejected, Hi accepted If significant value $\mathrm{F}$ arithmetic $\geq 0.005$ (F table), meaning Ho accepted, Hi rejected

From the table it is found that the significant value of $F$ is 0,000 . So here 0.000 $<0.005$ means Ho rejected, Hi accepted.Thus it can be hypothesized that there is influence of life expectancy index, education index, and income index on human 
development index.The value of p-value obtained gives a result greater than $5 \%$ ie $14.788 \%$, so it can be concluded that the variation of each observation is the same.

\section{Discussion}

The quality of the population can measure the Human Development Index Factors affecting the Human Development Indexare life expectancy index, education index and income index. By identifying the index, a benchmark can be used to measure. IPM figures provide a high level of achievement of activities undertaken by the state or region. The higher the value of HDI means the country/region, showing the achievement of human development the better. Supported by analysis using SPSS method, that is life expectancy index, education index and index, have Human Development Index factor. With the result of p-value obtained obtained gives bigger result of $5 \%$ that is $14,788 \%$, can be accessed every same person.

Supported by previous research by researchers such as Ayomi Surya (2014), Yamin (2017), Ernany (2016) et al showed that "The three indicators include life expectancy index, education index and income index affecting Human Development Index". One of the researchers examined the analysis of Human Development Index in Madiun City in 2003-2012. Based on the results obtained indicate that "the poverty level and open unemployment rate in SWP Madiun and surrounding areas greatly affect the growth of hotel and trade sector".

\section{CONCLUSION}

This study found that the existence of variables that significantly influence the indicators of factors affecting the Human Development Index are life expectancy index, education index and income index.The estimation result using Correlasion Pearson shows that $14.788 \%$ is the variation of each observation is the same.This proves that there is a relationship between each other between one variable with another variable. 


\section{REFERENCES}

Ayomi Surya. 2014. Analysis of the Influence of Main Sector Growth on Poverty Level, Unemployment Rate, and Human Development Index (HDI) in Unit Area Development MadiunAnd Surrounding Year 2003-2012. Journal Ilmiah. (Online), accessed on April 20, 2018

Charisma Kuriata Ginting S. 2008.AnalysisHuman Development in INDONESIA. (Online), accessed on November 27, 2014

Ernany Endah. 2016. AnalysisOf Effect Of Economic Growth, Total Of Human Development And Individual Development (Ipm) On Number Of Poor Population In District Of Berau. Journal of Economi. (Online), accessed on April 20, 2018

Gideonse Hendrik. 2015. Effects of Demography. Journal Of Teacher Education. Online, accessed on April 20, 2018

Jahan Selim dkk. 2016. Human Development Report 2016. New York: United Nations Development Programme.

Mohammad Bhakti Setiawan \& Abdul Hakim. 2013. Human Development Index INDONESIA. Journal of Economia. 9 (1): 19-21. (Online), accessed on November 27,2014

Ratih Dyah. 2007. Pembangunan Pendidikan dan MDGs Di Indonesia. Jurnal Kependudukan di Indonesia. 2(2). (Online), accessed on April 19, 2018

Surya Ayomi.2012. Influence Analysis of Main Sector Growth Rate on Poverty Level, Unemployment Rate, and Human Development Index (HDI) in Unit of Madiun Area and Surrounding Year 2003-2012.(Online), accessed on November 23, 2014

Tri Maryani.Journal.Human Development Index Analysis In Central Java Province Central Java.(Online), accessed on November 26, 2014

Yamin Muhammad Zulfikar. 2017. Analysis on Factors that Influence the Human Development Index of Malang Regencybased on Regional Approach and Panel Regression.Journal of Regional and Rural Development Planning. 1(2): 202-216. (Online), accessed on April 19, 2018 